\section{Strategies and alliances needed to protect forest from palm-oil industry}

SIR - Lian Pin Koh and David S. Wilcove propose in their Commentary 'Cashing in palm oil for conservation' (Nature 448, 993-994; 2007) that non-governmental organizations (NGOs) should purchase and operate oil-palm plantations, and that they should use the revenue generated to expand the network of private reserves in Indonesia and Malaysia.

Because this would delay the establishment of reserves in a landscape that is rapidly degrading, Reuben Clements and Mary Rose C. Posa in Correspondence ('Conservationists could slip up in palm-oil enterprise' Nature 448, 403; 2007) advise using available funds to purchase the reserves directly instead.

However, both strategies focus on purchasing land for reserves. In doing this, they are putting themselves in competition with a palm-oil industry that is worth more than $\$ 4$ billion in annual exports from Indonesia alone, according to the Food and Agriculture Organization (FAO, Rome, 2006).

Limited by their annual budget of only about \$12 million, Indonesian NGOs are unlikely to be able to afford the cost of establishing sufficient reserves. Instead, what we suggest is that they combine a range of approaches to conservation, in order to maximize their influence through strategic alliances.

These include joining in with local communities who can sway development away from palm oil towards more sustainable land use, and working with carbon off-setters to redirect deforestation and carbonsequestration payments to areas of high conservation value. NGOs should engage the palm-oil industry through the Roundtable on Sustainable Palm Oil and encourage them to implement practices that improve the conservation value of their estate. The NGOs should also work to support an economically and ecologically sustainable timber industry.

Reserves should be purchased only if and when doing so is a more cost-effective means of conserving biodiversity than any of the available alternatives: that is, when resources are available, the benefits are substantial and the alternatives are limited.

Increasing consumer awareness of the impact of palm-oil production on biodiversity - particularly on orangutans (Pongo pygmaeus) - is another important step. A resultant drop in the demand, by people concerned about the environment, for biodiesel from palm oil could curb the industry's growth.

The NGOs involved must move on to foster relationships that simultaneously work both with and against the palm-oil industry to limit its impact.

Oscar Venter ${ }^{\star}$, Erik Meijaard $\gamma^{\prime}$, Kerrie Wilson

*The Ecology Centre, School of Integrative

Biology, The University of Queensland,

Brisbane, Queensland 4072, Australia

†The Nature Conservancy, Tropical Forest

Initiative and Orangutan Conservation Services Program, Balikpapan, East Kalimantan 76100,

Indonesia

†The Nature Conservancy, 60 Leicester Street, Carlton, 3053, Australia

\section{Illegal mining could revive Xinjiang's coalfield fires}

SIR - Your Nature News story ‘50-year-old fire put out' (doi:10.1038/news.2007.281) mentions that an underground coal fire in Xinjiang's Terak coalfield in China has been extinguished, as has another, near Urumqi, that had burnt for 130 years. However, we remain unconvinced that the Terak coalfield fire will not reignite.

As a result of more than three years' efforts by the Xinjiang Coalfield Firefighting Project Office, the coalfield fire in Liuhuanggou, near Urumqi, was put out in 2004. We have been detecting signs of revival since 2005, however, including sporadic heat anomalies in sub-zones and smoke escaping from surface fissures. Local blocking of the fires has caused a redistribution of ground stress, resulting in new fissures connecting with the surface. These fissures allow entry of oxygen and promote heat circulation. Meanwhile, mining in the vicinity may have disrupted fire-suppression measures, causing new fire spots to start up around the previous fire zone.

Since 2005, the Liuhuanggou coalfield roads have been levelled to facilitate firefighting operations. Coal that was previously hard to extract can now be easily mined, illegally, from the coal-seam outcrops just by stripping the soil overburden that was once covered for the purpose of firefighting.

Illegal mining may also have helped to revive the fire. In coalfields in Xiaolongkou and Xiaohuangshan, for example, where fires had been confirmed as extinguished in 2001 by the Chinese government, illegal mining activities have already caused the fires to revive.

The Chinese government should prohibit uncontrolled mining activities and maintain long-term monitoring in and around the extinguished fire zones to prevent the fires from reigniting.

Maohua Zhong, Tairan Fu

China Academy of Safety Science and Technology,

State Administration of Work Safety, No. 17,

Huixin Xijie, Chaoyang District, Beijing 100029,

People's Republic of China

\section{Slow development impedes the uptake of diagnostics}

\author{
SIR - Two conclusions in your Business \\ story 'Missing the mark' (Nature 449, \\ $770-771 ; 2007$ ) about the usefulness \\ of cancer biomarkers should evoke a \\ response from translational researchers \\ and clinicians.
}

First, you say that the overall impact of early bladder-cancer detection on patient survival rates may be relatively small because surgery remains the treatment of choice. This may be why survival from bladder cancer has barely changed during the past two decades: more accurate early-detection tools, such as biomarker tests, are needed. Since the 1980s, the American Cancer Society has issued guidelines and recommended several early-detection tests because of their clinical benefits. These have led to an increased likelihood of complete tumour removal and therefore of a better outcome and reduced costs. Public-private partnerships are therefore expediting the development of biomarker diagnostic tools.

Second, you say that, in the absence of new drug therapies, "there isn't a huge incentive for doctors and the health-care insurers that pay for most medical services in the United States to buy the tests". But this is contrary to established fact. For example, DNA-based testing for human papilloma virus to augment or replace pap smears is widely accepted and reimbursed. Her-2/neu gene testing is necessary for breast-cancer patients undergoing treatment with Herceptin. The US Food and Drug Administration's approval in 2004 of EGFR-pharmDx (which detects colorectal cancers expressing epidermal growth-factor receptors) for treatment with the cancer drug Erbitux led to rapid uptake, with reimbursement by Medicare and private insurers in the United States.

The problem lies not with physician uptake and reimbursement, but with the slow development and validation of accurate tests providing useful information for early detection and treatment.

Chul-So Moon ${ }^{\star}$, Eddy C. Agbo ${ }^{\star}$,

David Sidransky'

${ }^{\star}$ Cangen Biotechnologies, Inc., 300 E. Lombard

Street, Baltimore, Maryland 21202, USA

†Department of Otolaryngology, Johns Hopkins University School of Medicine,

and Sidney Kimmel Comprehensive Cancer Center, Cancer Research Building II, 5N.03, 1550

Orleans Street, Baltimore, Maryland 21231, USA

Contributions to Correspondence may be submitted to correspondence@nature.com. Published contributions are edited.

Science publishing issues of interest to authors are regularly featured at Nautilus (http://blogs.nature.com/nautilus), where we welcome comments and debate. 